The Third Pole: Journal of Geography

Vol. 18 - 19: 85-96, 2019

DOI: https://doi.org/10.3126/ttp.v18i0.28009

Department of Geography Education,

Central Department of Education, T.U., Kathmandu, Nepal

\title{
PRESENT STATUS AND UTILIZATION OF THE MINERAL RESOURCES IN NEPAL
}

\author{
Devi Prasad Paudel, PhD $^{1}$
}

\section{Abstract}

This paper explores the present status and utilization trends of the mineral resources in Nepal. It is mainly due to mineral resources are playing vital role in the development of economy, industry and gross domestic products (GDP). However, the mineral resources are unevenly distributed across the geographical regions. In addition, some minerals are deposited in a particular place on a small scale. As a result, Nepal has not been able to mobilize mineral resources due to lack of detailed study. It requires rigorous study to identify the amount and quantity of mineral deposits in a particular area that can be dug out for commercial purpose. The data were mainly generated from a review of various materials and concludes that the government should give high priority to explore, excavate the mineral resources. It requires clear policy efforts and provisions regarding roles and responsibilities towards the proper mobilization of mineral resources through both private and public sectors. The commercial extraction of mineral resources helps to import substitution, industrial development, jobs creation and revenue collection.

Key words: Minerals resources, exploration, scatter, deposition and investigation

\section{Introduction}

The concept of resources is purely functional, inseparable from human wants and human capabilities. It is true that nature provides the opportunity for human to display their skills and apply their ever-expanding knowledge. This is the greatest because it is the mother of other resources (Zimmermann, 1951 cited from Mitchell, 1933). Human beings are both the most dynamic agents of production and the beneficiary of the entire process of resources development and utilization. By applying human skill, mind and power human beings are able to maintain survival through eking out different types of resources. Because resources are living phenomena expanding and contracting in

1 Dr. Paudel is an Associate Professor, Department of Geography Education, Central Department of Education, Tribhuvan University,Email: devipaudel11@yahoo.com 
response to human efforts and behavior (Mitchell, 1933; Zimmermann, 1951; Sanford $\&$ Moran, 1978). Mineral resources are also one of such resources, which has been used since ancient times to fulfill human needs. They are considered as non-renewable natural resources.

The mineral is defined as naturally occurring inorganic solids. They are usually chemical compound composed of two or more elements. It possesses unvarying physical properties, notably a distinctive crystalline form a particular structure, or a mode of fracturing (Zimmermann, 1951). The historical evidence shows that most of the ancient civilization used wood and stone for weapons and utensils before the invention of mineral resources. They had developed different lithic ages regarding their knowledge and skill towards tools making, such as Stone Age, Bronze Age, Iron Age and so on (Poudel, 2008; Kaphle, 2013).According to Stanford \& Moran (1978) "resources are not, they become"(p.262).They argued that a natural element does not become a resource until people perceive a use for it. This presupposes that a society has the technical skills to develop and use the resource and that it is economically feasible to do so. Thus, the term resources refer to those parts of the total earth environment useable under present technical, economic and cultural condition. It can be said that there are many types of mineral resources deposited in many developing countries, like Nepal. They can prepare a very long list, but we are unable to use these resources to earn economic benefit. In this sense, they have not become resources as stated by Stanford \& Moran (1978).

The mineral can be considered as a potential resource for the prosperity of Nepal. It is mainly due to Nepal is regarded as the richest in mineral resources. Some resources, like iron, copper, lead, zinc, cobalt, nickel, quartzite, dolomite and limestone are widely distributed across the country. However, these resources have not properly explored as per the need of Nepal due to the lack of capital, lack of technology, lack of skilled human power, lack of access to transportation, and lack of strong government policies towards the extraction of mineral resources (Sharma, Mahato \& Maharjan, 1988; Poudel, 2008; DMG, 2011; Khanal, 2017). In addition, some minerals are deposited in a specific place. For example, gravel, sand, ground water, petroleum and natural gases are mostly found in the Tarai while radioactive mineralsand coals found in the Churia range. Other metallic minerals, such as iron, copper, lead, zinc, cobalt, nickel, tin, gold, and uranium are placed in the Mahabharata range. The precious and semi-precious stones, marble and metallic minerals like lead, zinc uranium, gold are observed in the Himalaya region (Sharma, Mahato \& Maharjan, 1988; DMG, 2011; Khanal, 2017).

The government of Nepal has been initiated mineral exploration activities after the establishment of Department of Mine and Geology with the financial support of Mineral 
Exploration Development Project (MEDP) (Kaphle, 2013). The $9^{\text {th }}$ Five Years Periodic Plan has also given priority to explore, evaluate and mobilize sustainable development of mineral resources, research and establishment of mineral based industries with the cooperation of the private sector (NPC, 2002; NPC, 2019). However, all these policy efforts are not effectively worked for the study, excavation and proper utilization of mineral resources. As result, mineral resources are not enough to produce for economic values in Nepal. In this context, this paper attempts to analyze the unravel question regarding what is the present status and potential utilization of mineral resources in Nepal.

\section{Methods and Materials}

This paper is mainly based on secondary sources of data. Most of the information were collected from the reviews of existing literature regarding the present status and utilization of minerals resources in Nepal. The government policies and reports were reviewed for data generation. Similarly, archive documents, books and journals were also used. On the basis of literature, mineral resources can be classified into three broad groups such as metallic, non-metallic and decorative resources. The data collected from different sources have been analyzed on the basis of these classification using both analytical and descriptive methods.

\section{Results and Discussion}

Resources are the fundamental base of power, prosperity and wealth, if they are properly used by a country. In Nepal, local people had used different types of mineral resources in a small-scale through ancient times. They had used iron, copper, lead, zinc, cobalt, nickel mines as well as quartzite, dolomite and limestone quarries (Kaphle, 2013). Nepal has listed different types of mineral resources in different parts of the country. They can be classified into three broad groups. They are discussed as the following heads.

\section{Metallic minerals}

The metallic minerals are widely used for various purposes in human life. They are mostly extracted from their respective ores. A number of metallic ores are listed in different parts of Nepal. Among them some of the following major minerals are discussed here.

Iron (Fe): Iron deposition ores are mostly found in Phulchoki (Lalitpur), Thoshe (Ramechhap), Labdhikhola (Tanahu), Jirbang (Chitwan), and Dhuwakot (Parbat). Local people had excavated and used traditionally iron ore since ancient times in different parts of Nepal. But their utilization were only in the local area. The traditional iron ores 
were excavated in Baitadi, Bajhang, Jajarkot, Rolpa, Surkhet, Myagdi, Baglung, Parbat, Chitwan, Ramechhap, Okhaldhunga, Taplejung etc. The iron ore of Phulchoki has still been commercially utilizing due to its location. However, it lies in the environmentally sensitive area and suffering from various problems, like the shortage of power like the electricity and coal for smelting. Thoshe iron deposit was mined in small scale during the Rana period, now a days the mine has completely closed due to its lack of competition with processed iron in the market (DMG, 2011; Amayta, 1996; Kaphle, Joshi, \& Khan1995 1996, 2006).

Copper (Cu): Copperis an important metal and it can multiply used in Nepal, such as electric wire, telecommunication equipment, copper wires, crafts, making alloys, utensils, and other household purposes. It is deposited about 107 localities, including Gyazi (Gorkha), Okharbot (Myagdi) and Wapsa (Solukhumbu). Other areas like Kalitar (Makawanpur), Dhusa (Dhading), Bamgaun (Dadeldhura), Khandeswori/ Marma (Darchula),Kurule (Udayapur), Bhutkhola (Tanahu), Pandavkhani (Baglung), Baiskhani (Myagdi), Mianmkot (Syangja), Chhirlingkhola (Bhojpur), Jantarakhani (Okhaldhunga) are also famous for the deposition copper (GoN, 2011).

Zinc ( $\mathbf{Z n )}$ and Lead (Pb): Zink is deposited in more than 54 locations in Nepal. The zinc ores are associated with Sphalerite and Galena and mostly found in the Ganesh Himal area (Rasuwa), Phakuwa (Sankhuwashbha), Libangkhairang, Damar, and Baraghare (Makawanpur), Pangum (Solukhumbu), Salimar valley (Mugu/Humla),Phulchoki (Lalitpur), Sishakhani and Khandebas (Baglung), Duwakot (Parbat) Bhalu Danda (Dhading) and Kholakhani of Taplejung distric (Kaphle, 2013). Among them only Ganesh Himal Zinc- Lead deposits (Lari and Suple) has been proven as an economic deposits and underground mine development work was completed by Nepal. Metal Company long time before but there is no production yet. Due to the small size of the deposits, its location in the remote area and fall of lead price in the international market is the major causes behind not running the mine in spite of the commercial grade. Zinc is mainly used in galvanizing iron, dry battery, pigments, soldering, dyeing, glue making etc.

Cobalt (Co): Cobaltite is the main cobalt ore. Other ore minerals like erythrine and absolite are also recorded in different prospects. Few old workings for cobalt are known from Netadarling andTamghas (Gulmi) and Samarbhamar (Arghakhanchi). They are also recorded from Lamadanda (Dhading) Nangra (Kavre), Bhorle (Ramechhap), Bauli Gad (Bajhang), etc. All these oldworkings/ prospects need proper review and evaluation before further exploration. Cobalt is mainly used in making high resistant steel and alloys and also in glass factories to produce blue colored glass. 
Nickel (Ni): It is occurred in a form of few polymetallic sulphide deposits like in Bamangaun (Dadeldhura), Beringkhola (Ilam), Bauligad (Bajhang) Khoprekhani (Sindhuli) and old workings from Nangre and Bhorle (Kavre) area Nicclide and Pentlandite are the chief ore minerals. Nickel is mainly used in making steel, cast iron, bronzes, brasses and alloys of chromium, lead, cobalt, manganese, aluminum, silver and gold. Nickel is mostly related to basic and ultrabasic rocks in its origin.

Gold (Au): It is a precious metal which is widely used in making coin, ornaments, jewellery, dental appliances, electroplating metal coating and many other purposes. In Nepal alluvial/ places gold are frequently collected by local dwellers (Botes) from river gravel/ sediments deposited by the rivers like Mahakali, Chamaliya, Jamari gad, Seti, Karnali, Bheri, Rapti, Lungrikhola and Phagumkhola (Rolpa), Kaligandaki, Myagdikhola, Modi, Madi, Marsyandi, Trishuli, Bhudhi Gandaki, and Sunkoshi along their high and low flood plains as well as terraces, Primary gold occurrences are known from Lungrikhola area (Rolpa), Bangabagar, Gorang and Jameri gad (Baitadi), Bamangaun (Dadeldhura) but they are yet to be evaluated by detail exploration.

Silver (Ag): It is mainly used to make ornaments, jewellery, coins, handicrafts, utensils, dental appliances, and in many other purposes. It is generally associated with zinc- lead ore and in gold. In Nepal minor amount of silver is reported in the zinc- lead ore of Ganesh Himal (Rasuwa), Barghare (Makawanpur), and polymetalsulphide of Bering Khola (Ilam).

Tin (Sn) is mainly used in making brass and bronze alloys, coating, lining, plating the food containers in chemicals etc. It is recorded mainly at Meddi and Genera (Dadeldhura) and Mandhukhola area (Makawanpur). In-situ Cassiterite mineralization and cassiterite rich floats are seen in Meddikhola.

Uranium (U) and Thorium (Th): They are known as radioactive elements in Nepal. Uranium is mainly used in nuclear power generation, nuclear medicine, atomic weapons, technical and industrial appliances, agriculture, age dating of rocks etc. Radioactive minerals like autonite are recorded from Thumki, Jagat, Panchmane, Gagalphedi, and Chunikhel in Shivapur area in Kathmandu. Few other ores of uranium like uranite, tynamunitecarnotite and coffinite are also known from Tinbhaangale, Chandi. Khola and Chiruwakhola (Makawanpur), Bukakhola (Sindhuli) Mardarkhola and Panpakhola (Chitwan), Jamari gad, Bangabagar, Baggoth, Gorang (Baitadi), and Traces in different section of Chamaliya River (Darchula). 
Bismuth (Bi): It is mainly used to make alloys with antimony, lead, tin and cadmium, in medicine and cosmetic items. Mineral like bismuthinite is reported from Bamangaun polymetalsulphide deposits in Dadeldhura and Baraghare and Mandukhola area in Makawanpur district.

Cinabar is the chief ore of Mercury (Hg). It is reported from Tirche Pani/Taruka. Talalov (1972) reported cinnabar from the heavy concentrate sample from Khimti River and Zinc- Lead ore from Pangu Mercury, which is mainly used in pharmaceuticals, thermometer, electrical apparatus, insecticides etc.

Berllium (Be) can be extracted from beryl and aquamarine which are known from the pegmatites of Khaptad and different parts of Manang, Kathmandu, Nuwakot, Rasuwa, Phakuwa Hyakule, Ilam and Taplejung districts.

Arsenopyrite is the main sources of Arsenic (As), Arsenopyrite is mainly associated with pyrite and pyrthotite in polymetalsulphide deposits e.g. in Bamangaun and Bering Khola. Occasionally arsenopyrite is also the pathfinder for gold mineralization. It is commonly used in making lead shots, dyes, pigments, insecticide, and medicine and in many chemicals.

\section{Non-metallic minerals and its utilization}

A number of non-metallic minerals like magnesite, phosphorite, talc, limestone, dolomite, quartz, mica, clay, silica sand, gemstones, decorative and dimension stone, construction materials etc. are known to have identified from different parts of the country. Some important ones are briefly discussed below.

Limestone. It is very important raw material for making cement. With the rapid increase of development activities such as construction of roads, bridges, dams, irrigation cannels, housing complexes, multistory building etc. the demand of cement is increasing. Some lime-stone deposits have been identified in Khotang, Udayapur, Syangja, Palpa, Arghakhanchi, Dang, Pyuthan, Sallyan, Rolpa, Bajhang, Baitadi, and Darchula, districts. Preliminary studies indicate that there is a possibility to find more than 2.5 billion tons of cement grade limestone and 196 prospecting licenses of limestone have issued by DMG to private sectors (GoN, 2011). But, in some areas of Palpa district there is conflict between local people and company due to the unclear minerals policy.

Dolomite. It is used in construction materials, mainly in road paving, house construction, and in all other civil construction works. Some dolomite could be used as flux in 
steel industry and as filler in glass industry. It occurs mainly in Dhankuta, Khotang, Udayapur, Sindhuli, Dolakha, Kavre, Kathmandu, Makawanpur, Dhading, Syangja, Palpa, Baglung, Gulmi, Arghakhanchi, Dang Pyuthan, Sallyan, Rolpa, Rukum, Jajarkot, Surkhet, Dailekh, Jumla, Achham, Doti, Bajhang, Bajura, Baitadi, and Darchula districts in the Lesser Himalayan and in some parts of Higher Himalayan region. Most of them are not yet explored in detail and their grade and quality to utilize raw materials for industries is still unknown.

Phosphorite. It is one of the main raw materials to manufacture chemical fertilizers like fused magnesium phosphate triple super phosphate, etc. The phosphorite is confined to massive cherty and stromatolite dolomite of Pre-Camberian to Lower Paleozoic age that occur in Dhick Gad, Junkuna, Morgaon, Sanagaun and Dhaubisaune areas in Baitadi, Far Western Nepal (Bashyal, 1984).

Magnesite is used to manufacture fused magnesium phosphate (FMP) fertilizer, production of chemicals, in glass, sugar copper, petrochemical and pharmaceutical industries. Kampughat in Udayapur district, and few small size magnesite occurrences have been identified in Palpa, Baitadi, and Dolakha. Kharidhunga magnesite deposit is one of the biggest and best quality magnesite in south Asia.

Talc/Mica- Talc is used in cosmetics, paper, plastic, ceramic, paints, soaps, plasters, leather and soap factories. Different studies show that Talc schist is found in different parts of Lalitpur, Dolakha, Sindhupalchok, Dhading, Chitwan, Tanahu, Kaski, Syangja, Surkhet, Bajhang, Bajura, Baitadi, and Darchula districts. In all these places small scale mines are in operation. Similarly, minerals coarse size mica books are recorded only in complex pegmatite bodies from Langtang (Rasuwa), Bhumidanda and Khairenitar (Nuwakot), Chaukibhanjyang (Kathmandu), Nibuwagaun (Sindhupalchok) Khaptad (Bajhang), Baskot and Bhasukan (Doti), Fical (Ilam), Mica being non-conductor of heat and electricity they are widely used in electrical goods and as fire proofing and sound insulation materials.

Ceramic clay/ Red clay is used in pottery industries. Huge amount of silty Clay deposits in different parts of Kathmandu valley is used to manufacture bricks. In villages it is used in house wall painting.

Pyrite is mainly used to extract Sulphur and manufacture sulphur compound e.g. sulphuric acid, ferrous sulphate. It is found in Bering Khola (Ilam), Chhirlingkhola (Bhojpur), Meddi and Bamangaun (Dadeldhura) and some other places mainly in polymetal sulphide deposits forms. Pyrite as such has not been mined in Nepal. Similarly, 
Silica sand is used in glass industry and other purposes. There is a possibility to find similar sand deposits in similar environment in many parts of the country.

Graphyte is mainly used in lead pencils, foundry facing crucibles, paints, lubricants etc. It is one of the significant minerals in metamorphic terrain in Lesser Himalayan region. They are reported from Ilam, Dhankuta, Sankhuwashbha, Nuwakot, Sindhupalchok, and Dadeldhura. It may occur at many places of the country but proper recording has not been made during mapping.

Diatomite is reported from Chobhar, Thimi, Bode and few other places in Kathmandu valley. Small scale mining of diatomite is in operation in Thimi and Bode. It is mainly used in white washing sound and heat insulation and as filler.

Different types of marbles are used as decorative stones in the form of block and stabs. Pink, gray and white colored marble deposits are located in Godavari, Lalitpur district. Granite is also known from Makawanpur, Sindhuli, Udayapur, and Dadeldhura in the Lesser Himalaya. Course granite, massive granites are used as decorative and dimension stones. Quartzite is another hard type of metamorphic rock which consist of mainly quartz. It is common rock and abundantly known from Taplejung, Illam, Dhankuta, Ramechhap, Sindhupalchok, Makawanpur, Dhading, Tanahu, Kaski, Syangja, Parbat, Baglung, Achham, Doti, Bajhang, Bajura, Dadeldhura, Baitadi, Darchula and few other districts. It is mainly used as dimension stones, flagstone for paving purpose and as construction materials.

\section{Fuel minerals}

Coal in Nepal, medium to low grade occurrence/ deposits are known in four stratigraphic positions e.g. i) Quaternary lignite ii) Siwalik coal iii) Eocene Coal and iv) Gondwana coal Peat/ lignite in Kathmandu valley is mined in brick burning. Siwalik coal is not economically attractive because of scattered small lenses. Eocene coal occurs as irregular seams confined to orthoquartzite in Tosh, Siuja, Azimara and Abidhara in Dang, Sallyan, Rolpa, Pyuthan and Palpa districts.

Petroleum and Natural Gas, a number of Oil and Natural gas seeps are recorded in stretch of about $14 \mathrm{~km}$ in Padukasthan, Sirsesthan and Navisthan area in Dailekh and only gas seeps in Muktinath in Mustang. GoN /DMG Petroleum Exploration Project (PEPP) are giving high priority to explore and promote petroleum exploration in Nepal since 1982. 
Methane gas deposit in Kathmandu Valley is known since long time. They are dissolved in water biogenic gas (methane). A model of gas plant is set in Tripureswor/ Teku. Feasibility study has confirmed that the gas can be used for industrial and household purpose and the reserve is sufficient to supply gas to 21000 families for about 30 years (GoN, 2011).

Geothermal hot spring-Twenty-three thermal spring are so far identified in the country, of which twenty are associated close to the Main Central Thrust (MCT). Their utilization is currently limited in hot water shower/ bath and therapeutic application (DMG, 2011). Likewise, radioactive minerals like Uranium are known from Sindhuli, Makawanpur, Kathmandu and Baitadi districts. There is a high possibility to find such minerals in the granite terrain (granite, gneiss and pegmatite) in Higher and Lesser Himalayan region as well as from the Siwalik sandstone. Uranium is a major source of fuel for the production of Nuclear Energy.

All these above mentioned the metallic, non- metallic and fuel minerals indicate that Nepal has high potential for development. Exploration activities in the past have revealed that most of them are small in size, low to medium in grade and sub-economic to non-economic deposits. However, non-metallic minerals rocks such as marble basalt granite and red sand stones are more utilized in comparison to metallic minerals.

\section{Major problems}

Because of unclear government policy for the development of mineral resources,foreign investors are not encouraged to invest their capital in Nepal in those areas. Other problems of mineral resources in Nepal such include low rate of capital formation, limited scope of market and lack of interest at the government and people level. Some contradiction between some clauses of the Mine and Mineral Act and Regulation, Forest Act and Regulation and Local Self Government Act and Regulation (Forest Act, 1993 and Local Self Government Act 1999) have also put constraints in minerals exploration and exploitation. The procedure to get permission for mining of any mineral commodities in the forest area by Department of Forest is lengthy and difficult. Environmentalists also express concerns some time create unnecessary problems time and again (Environment Act, 1997). Many known mineral resources in the Himalaya and Sub- Himalaya regions are still not exploited because of lack of infrastructures like road access, electricity, communication, water supply etc. The potential investors are less interested since mineral exploration, mine development and establishment of a mineral based industry normally requires above mentioned infrastructures. There is high risk, uncertainty and long return period. Systematic geological understanding of the process of Nepal Himalaya 
is also lacking. Moreover, lack of different types of geological map at different scales, technologies and concept of exploration of minerals, studies in minerals genesis, and the concept for exploitation of scattered deposits remains major constraint in this field. Nepal is located between two giant countries China and India that can be considered the problems of minerals utilization of Nepal due to their high extraction capacity of minerals. Lack of advanced technology, lack of finance and investment, limited scope of market; defective government policy and inadequate supply of energy are the major problems in exploration, exploitation and development of mineral resources in Nepal.

\section{Conclusion}

There is disparity between the different types of mineral resources position and utilization in Nepal. Some mineral resources like boulder, sand, gravel, slate, granite and lime stone which do not require more financial resources to explore and exploit are in high use, while other like energy resources and metallic minerals are underutilized. Most of the information on minerals occurrences in the country is still sketchy. Lack of a substantive and comprehensive geological survey continues to be a great constraint in the way of exploration of economic minerals in the country. As a result, till now Nepal has no big minerals of economic importance as resource base. Metallic minerals of medium grade economic importance so far found are lead and zinc mines of Ganesh Himal, iron ore of Phulchoki, and magnesites of Kharidhunga. These could be of significant use for development. The existing Acts and Regulations such as the Forest Act 1993, Environment Act 1997 and programs and activities of government at all levels have overlapping provisions and arrangement in dealing with the issues of mines and mineral resources. These needs to be resolved for smooth use of these resources for the economic development of the country.

Finally, massive study and investment is required in the part of government to explore and locate mineral resources and exploit them for the prosperity and progress of the country. It is equally important that the government should take all measures to ensure the impact on natural environment will be less in the entire process. Government should bring out appropriate minerals policy, in coordination with provincial and local government levels. Therefore, further detail research in the known areas, evaluation of specific deposits and exploration in the new geologically prospective areas may help to find the potential economic deposits of various metallic resources in Nepal. 
Devi Prasad Paudel / Present Status and Utilization of the Mineral Resources in Nepal

\section{References}

Amatya, K. M. (1996). Geological and mineral resources of Nepal an overview. A paper presented at 30 ${ }^{\text {th } I n t e r n a t i o n a l ~ G e o l o g i c a l ~ C o n g r e s s ~(A u g u s t ~ 4-14 ~ 1996) ~}$ Beijing.

Bashyal, R. P. (1984). Phosphorite exploration in Nepal: Its present status and future prospects. Kathmandu: Department of Mines and Geology.

Eggert, R. G. (2010). Mineral exploration and development: Risk and reward. USA: Division of Economics and Business Colorado School of Mines pp.1-15.

Government of Nepal. (2004). Mineral resources of Nepal. Kathmandu: Government of Nepal, Department of Mine and Geology.

- (2011). Mineral resources of Nepal. Kathmandu: Government of Nepal, Department of Mine and Geology.

GoN. (1999). Local self-governance act 1999. Kathmandu: Government of Nepal.

HMG. (1993). Forest act, 1993. Kathmandu: HMG.

HMG. (1997). Environment Protection act 1997. Kathmandu: HMG.

Kaphle, K. P. (2006). Industrial mineral deposits and investment opportunities in Nepal. The Nepalese journal of industry, commerce and supplies, 2, pp. 55-67.

(2013). Minerals mines and mining activities in Nepal. Environment and natural resources. Special Issue, pp. 282-300. Kathmandu: Nepal Academy of science and technology (NAST).

Kaphle, K. P., Joshi, P. R. \& Khan, H. R. (1996). Placer gold occurrences along the major rivers of Nepal Himalaya and their possible primary sources. Journal of Nepal geological society, 13 pp. 51-63.

Khanal, R. P. (2017). Mines and mineral in Nepal: Unearthing the path to prosperity. Kathmandu: Ministry of Industry, Department of Mines and Geology.

NPC. (2019). Fifteenth plan, approach paper (2019/20-2023/24). Kathmandu: National Planning Commission.

NPC. (2002). Tenth plan, 2002-2007. Kathmandu: National Planning Commission.

Poudel, K. P. (2008). Fundamentals of resource management. UK: LAP LAMBERT Academic publishing $\mathrm{GmbH} \& \mathrm{Co.KG}$. 
-(2012). Resource management: A geographic prospective. The third pole, Journal of Geography, Kathmandu, Nepal: Department of Geography Education, Volume11and12, pp. 21-28.

Sharma ,Y. P., Mahato, S. P. \& Maharjan, S. R.(1988). Report on evaluation of river gravels of Tarai region of Nepal. Kathmandu, Department of Mines and Geology.

Stanford, Q. H. \& Moran, W. (1978). Geography: a study of its physical elements. New York: Oxford University Press p. 262.

Zimmermann, E. W. (1951). World resources and industries: A functional appraisal of the availability agricultural and industrial materials (Revised edition). New York: Harper and Brothers Publishers. 